\title{
Article
}

\section{The Political Economy of Russian Migration Politics}

\author{
Vladimir Malakhov ${ }^{1,2, *}$ and Mark Simon ${ }^{1,2}$ \\ ${ }^{1}$ Center for Political Theory and Applied Political Science at the Russian Presidential \\ Academy of National Economy and Public Administration (RANEPA), Moscow 119571, \\ Russia; mr.marksimon@gmail.com \\ 2 Moscow School of Social and Economic Sciences (MSSES), Moscow 119571, Russia \\ * Correspondence: vmalachov@yandex.ru
}

\begin{abstract}
The authors argue that despite significant numbers of foreign workers present in the Russian labor market Russia remains unattractive for highly skilled foreign workers. The economic crisis the country has faced since 2014 has resulted in a further outflow of foreign nationals from OECD countries. So Russia has to look for employees among newcomers from the former Soviet states, the majority of whom come from Central Asia. Russian politics with regard to immigration is characterized by the collision between "geopolitical" and domestic policy rationales. On one hand, seeking to maximize its influence in the postSoviet space Russia provides preferential conditions of employment for citizens of partner countries in the framework of the Eurasian Economic Union. On the other hand, the Kremlin is afraid to liberalize its approach to immigration and the integration of immigrants through fear of losing popularity among the electorate. The second substantial feature of Russian immigration politics is an extreme level of securitization of migration issues. The government considers these issues primarily through a policing lens. One cannot claim that the Russian state does not take any steps to liberalize "migratory regulation"; however, the effect of these measures is being vastly reduced by new restrictions. In addition, liberally designed laws do not bring the expected results due to the corrupt practices that pervade the whole of migration regulation.
\end{abstract}

Keywords: labor migration; migration policy; Russia; Post-Soviet space; governmentality; labor legalization

JEL Classifications: J68, J61, J40, J46

\section{Introduction}

Garry Freeman (1995) [1] once made the point that a significant factor determining the dynamics of immigration policy in liberal democracies is the collision between the needs of business for (cheap) labor and the unpopularity of the importation of labor among the voters. Business has to grow, politicians have to be reelected. As a result, immigration policy tends to be more liberal in practice and more restrictive in rhetoric. Russia seems to be a fairly typical case in this 
context. It is tempting to side with Andrei Schleifer and Daniel Treisman (2003) [2], who suggested that we see Russia as "a normal country". However, we would be better advised not to yield to this temptation. The Russian case is rather specific.

First, for twenty-five years Russia's borders with most post-Soviet states have remained open: there is a visa-free regime in place with all the newly independent states (NIS) except Turkmenistan and Georgia. That is why millions of foreign workers are entering the Russian labor market every year, many of them without a work permit. At least half of these foreign workers are employed in the 'grey' zone of the national economy. They come to Russia legally, but they work illegally. (Hence the expression "illegal immigration" must be used with some qualification in the Russian case.)

Second, today's Russian Federation apparently cannot be included among the liberal democracies. The political system shaped in Russia during the last decade is such that policy makers enjoy more room for maneuver than their counterparts in the West. Russian officials are much less dependent on public opinion (which is subjected to effective manipulations through state controlled mass media). They face few constraints in turning to repressive measures - they have no need to go through exacting parliamentary debates; as for grass-roots political organizations with an anti-immigrant agenda, the authorities can simply ban them. At the same time nontransparent decision-making and the lack of civil society feedback lead to unprecedented corruption and arbitrary behavior by officials. As a result, corrupt practice in such administrative spheres as migratory regulation has become proverbial.

Third, the Russian state's treatment of immigration is riddled with contradictions between "geopolitical" and domestic political priorities. On the one hand, the policy of expanding Russian influence at the former periphery of the "Soviet Empire" ("Eurasian integration") implies increasing immigration inflows from Central Asia. On the other hand, the strengthening of national sovereignty (loudly proclaimed after the Ukrainian crisis in 2014) implies protecting the national labor market and restricting immigration, especially from Central Asia.

This article will first give an overview of labor migration into Russia in terms of its volume, structure, and role in the Russian economy. It then considers the Russian state's immigration policy before concluding with some reflections on the governmentality behind this policy.

\section{Structural Parameters of Labor Migration in Russia}

\section{1 Who Are the Immigrants in Today's Russia?}

From the second half of the 1990s onward the Russian Federation has been the main center of attraction for labor migrants in the post-Soviet space. After Russia recovered from the 1998 economic crisis, a quite stable structure of international economic migration took shape. People from the countries of the former Soviet Union (NIS) make up five-sixths of the total immigration flow (Mihaylova, 2016) [3] (p. 5). The share of non-NIS countries as labor suppliers has 
been steadily declining since 2007 . This process has accelerated since the preferential treatment of migrants from countries with visa-free entry was established. According to the Federal State Statistics Service the number of entries to Russia from the NIS is approximately 90 percent of the total number of entries [4]. In terms of work permits issued in 2010-2014 the share of NIS citizens accounted for 83-86 percent of the total number of employed foreign nationals (Trud i zaniatost' $v$ Rossii, 2015 [5]; Florinskaya et al., 2015 [6]). Even though these data do not include those migrants who are working without permits, the ratio between NIS nationals and newcomers from other countries will not vary significantly.

The major labor suppliers among the non-NIS countries are China (6.9 percent of work permits at the end of 2014), North Korea (2.9 percent), Turkey (2.3 percent) and Vietnam (1.3 percent). As to the workers from EU countries and the USA, their total share is 1.1 percent (Trud i zaniatost' $v$ Rossii, 2015) [5].

It is noteworthy that the majority of immigrants come to Russia for a relatively short period of time. The phenomenon we are seeing here is to a large extent temporary migration. Migration for settlement, meanwhile, has mostly involved former Soviet citizens (the majority were Russians or Russian speakers) who moved to Russia from the Soviet periphery either shortly before the collapse of the USSR or soon afterwards. Consequently, the description of Russia as the "second-largest migration system" in the world needs to be revisited (Malakhov et al., 2015) [7].

\subsection{How Many Migrants Are There in the Russian Labor Market?}

It is not easy to determine the exact number of foreign workers employed in the Russian labor market because nobody knows how many of them work without permission. By the end of 2014 there were 3.1 million work permits issued to "external migrants".

Yet there are no statistics concerning the employment of persons with residence permits, nor concerning employees from Eurasian Economic Union (EAEU) states, who do not need to obtain authorization to work. Summarizing all the above-mentioned categories of foreign workers, we obtain the approximate number of 3.5 million. In addition, the volume of undocumented workers is comparable to that of documented ones. In 2015, the Federal Migration Service (FMS) estimated the number of undocumented migrants at 2.5 million people (Romodanovsky and Mukomel, 2015) [8]. However, most experts agree that this number should be increased by at least one million (Chudinovskikh et al., 2013) [9]. Thus, the total number of migrant workers is estimated at 6-7 million people, which corresponds to 8-9 percent of all those employed in the Russian labor market - a figure comparable to the percentage of foreign workers in countries such as Germany, Belgium, Spain, and Norway. 


\subsection{Migrants and the Division of Labor}

Migrant labor is widely used in various branches of the Russian economy. Some economic sectors, such as construction, housing maintenance and utilities, and transport are structurally dependent on migrant labor. ${ }^{1}$ This dependency plays a much greater part in the hiring of migrant labor than other factors Russian employers might consider, such as saving on production costs (through the high rate of exploitation of migrant workers and non-payment of contributions to social insurance funds) (Lunkin et al., 2010) [10]. According to surveys of businessmen, migrant workers are hired primarily in medium and large enterprises. Small businesses use foreign labor half as frequently as medium and large businesses (Varshavskaya and Denisenko, 2014) [11].

Before the ongoing economic crisis about one third (28 percent) of migrant workers were employed in construction, 23 percent in households, 13 percent in industry, 12 percent in trade and consumer services, 8 percent in real estate and finance, 6 percent in agriculture, 4 percent in transport, and 2 percent in housing and communal services (Ryazantsev, 2016) [12].

However, these figures ought to be treated cum grano salis. The truth is that foreign workers are concentrated in the branches of the economy in which informal employment is the most common (construction and trade, agriculture, transport, and consumer services).

The informal economy should not be confused with the shadow economy. ${ }^{2}$ Informal employment is widespread in the Russian labor market but is considerably higher among immigrants than among local workers. Whereas about 20 percent of Russian workers are employed in the informal economy (about 14 million people), ${ }^{3}$ informal employment among immigrant workers in certain sectors reaches 80 percent (primarily in construction and the provision of personal services) (Analiz praktik trudovykh otnoshenii migrantov, 2013) [14].

Available sociological surveys of employers suggest that the main reason that encourages businesses to hire undocumented foreigners is the extremely corrupt procedure for obtaining the relevant documents. More than a third (36 per cent) of the surveyed businessmen claimed that obtaining a permit to employ foreigners requires too much effort, time, and money. Other reasons are (a) the desire to save on taxes and deductions (a fifth of small and medium entrepreneurs and an eighth of large business owners); (b) the opportunity to pay foreign workers less than natives ( 23 per cent of small businesses, 26 per cent of medium businesses and 18 per cent of large enterprises); and (c) greater compliance of foreign employees than local - they are easier to dismiss and easier to manage (Turukanova and Florinskaya, 2012) [15].

Informal recruitment is highest among the youngest age group - two-thirds of migrants under the age of 20 years (65.3 percent) work informally. Among 5059 -year-olds half are informally employed (51.6 percent). Informal hiring is fostered by a lack of vocational education. Two-thirds of immigrants with primary or lower secondary education are involved in informal employment. Of those with 
higher education, fewer than half (49 percent) are employed informally (Varshavskaya and Denisenko, 2014) [11] (p. 95).

\subsection{A Low-skilled Workforce vs. Highly Skilled Labor Migration}

Following the example of the majority of Organisation for Economic Cooperation and Development (OECD) countries Russia has established preferential treatment to encourage the hiring of highly skilled foreign workers. Preferences were provided in the form of tax breaks, simplified work permits without a quota, the possibility of concluding long-term employment contracts (up to 3 years) with repeated renewal, a simplified procedure for obtaining a residence permit for themselves and their family members, and easier access to Russian citizenship. Despite the actions taken, Russia remains unattractive for highly skilled migrants. From July 2010 (when the program to attract them was launched) to the present only 120,000 individuals have received corresponding work permits. The majority of the highly skilled workers in Russia originated from non-NIS countries (EU member states, China, Vietnam, Turkey and the USA). They are employed mainly in Moscow, Moscow region, and St. Petersburg.

Qualified workers represent a slightly larger influx of laborers, compared to highly skilled specialists. In 2014 their number amounted to 147,857 people. ${ }^{4}$ So the lion's share of all labor migrants in Russia consists of low-skilled workers.

\subsection{The Impact of the Economic Crisis on Immigration to Russia}

The economic crisis that began in 2014 was caused both by external and internal factors. The consequences of the economic recession obviously had an effect on the migration situation. First of all, the contribution of migration to population growth palpably declined. In 2015, immigration provided Russia with a population increase of 246 thousand people. ${ }^{5}$ In previous years, such a low level of increase was registered only in 2002 (Florinskaya and Mkrtchyan, 2016) [18]. 64 percent of the increase was provided by forced migration from Ukraine.

Apparently, the potential increase of arrivals from the Central Asian republics to Russia has gradually exhausted itself. At the same time significant partners in longterm immigration among non-Commonwealth of Independent States (CIS) countries are not yet visible. Even the vast majority of Chinese citizens come to Russia as temporary labor migrants. The number of foreign citizens temporarily residing in Russia has declined since the spring of 2015. While the number of citizens of the EAEU member states (Kazakhstan, Belarus, Armenia and Kyrgyzstan) living in Russia has increased, the number of citizens from all other CIS countries has decreased, especially from Uzbekistan (by 23 percent) and from Tajikistan (by 19 percent) (Maleva et al., 2016) [17].

The decline in the number of foreign citizens from the developed countries of the West was particularly acute during the crisis. In general, the number of people from EU member states, the USA, and Canada (i.e., the countries that supply the Russian Federation not only with tourists but also with highly skilled 
workers, investors, and businessmen) in the period from 2013 to 2015 decreased by 60 percent. In the first 10 months of 2015 the number of issued work permits for highly skilled workers from the US decreased by 50 percent, from Germany- by 58 percent, from the UK - by 68 percent (Ibid.) [17]. Simultaneously the number of highly skilled workers from Vietnam and China significantly increased.

Thus, at the very beginning of the crisis the structure of the Russian labor market changed in the direction of greater employment of migrant workers in private households. In 2014, 65 percent of foreign workers were employed in this sector of the economy, and 11 percent - in service industries, while only 10 percent of them continued to work in construction (Ryazantsev, 2016) [12]. ${ }^{6}$ Due to the current recession, fewer jobs are available in the construction sector, while the demand for foreign labor in the service sector (catering, restaurants, personal services) has not declined. Immigrants demonstrate more flexible employment strategies (compared to the local population), since they are willing to pursue a greater variety of jobs.

\section{Understanding Russian Governmentality}

\subsection{The Collision of Two Approaches to Migratory Regulation}

The development of migration policy in contemporary Russia can be considered as wavering between two logics - police-centric (which generates restrictive measures) and economy-centric (which leads to liberalization). The former tends to prevail over the latter. Some bifurcation points may be distinguished in this regard. At the turn of the twenty-first century a vast expert debate took place over the elaboration of a long-term strategy of migratory regulation. The debate was to have resulted in the so-called "Concept of Russian Migration Policy". Initially the Concept was designed in quite a liberal way. It stated that the regulation of migration processes should be aimed at ensuring sustainable socio-economic development by maximizing the intellectual and labor potential of immigrants (Mukomel, 2005) [19]. However, this document was not approved. Its final version, entitled "The Concept of Regulation of Migration Processes in the Russian Federation" (adopted in 2002), showed a radical shift in goal-setting. This latter version focused on the suppression of "illegal migration". It thus indicated an apparent drift to securitization in migration policy. In the same year, legislation was adopted that considerably complicated the legalization of workers from the NIS. ${ }^{7}$

The "policing" approach to migration policy that gained momentum at that time manifested itself at the institutional level. In May 2000, the Russian Federal Migration Service (FMS) was abolished; its functions were transferred to the Ministry of Federal Affairs, National and Migration Policies. In 2001 the FMS was incorporated into the Ministry of Internal Affairs. As a result, the majority of civil servants with experience working with NGOs in immigrant integration left the 
agency. In 2004 the FMS was transferred to the direct control of the Russian President.

Police raids against "illegal migrants" and the inspection of enterprises, both widely used in Russia since 2002, have proved ineffective. The number of undocumented migrants has continued to grow (Ivakhnyuk, 2014) [20]. In addition, grim expert forecasts concerning Russia's demographic prospects came to the attention of the highest authorities; these forecasts suggested that the ablebodied population of Russia will rapidly decline after 2006, and from 2010 the losses will comprise up to 1 million people per year (Ibid.) [20].

These concerns have prompted a liberalizing turn in migration policy. In 2007 new laws came into force that envisaged more favorable conditions for the employment of migrants from the CIS states. ${ }^{8}$ It became possible for foreign workers to change employers, as they could receive a work permit themselves. Furthermore, the period of temporary stay in Russia was increased for citizens of CIS countries. However, soon after these legal innovations were introduced they became subject to numerous exceptions. While in 2007 the quota was set at a rate of 6 million work permits, the following year (2008) it was reduced by almost half - to 3.4 million. ${ }^{9}$ Due to the decrease in quotas a significant portion of foreign workers has been pushed into the shadow economy. It is noteworthy that the Russian authorities took restrictive steps before the onset of the global economic crisis. The crisis, in turn, has exacerbated the spread of the Russian state's restrictive logic. In 2009, the government took measures to restore the fixed binding of worker to employer and thereby actually brought back the situation that preceded the reform of 2006 (Ibid.) [20] (p. 9). Thus, the positive effects of liberalization were soon offset by subsequent restrictions.

The next significant innovation in the regulation of migration was made in 2010 , with the introduction of the system of "patents" for carrying out work by foreign nationals for physical persons. Citizens of countries that have a visa-free regime with Russia were given the right to be hired in private households. The procedure to obtain a patent was much easier than acquiring a work permit. The lack of a quota for the issuance of patents, as well as their relatively low initial cost, contributed to the growth in demand for this form of legalization of immigrant labor. ${ }^{10}$

In 2015 the system of quotas for immigrants' work permits was abolished. Instead patents were extended to permit work for legal entities. This can be seen as a step favoring employers, as it allowed the demand for foreign labor to be determined by employers' assessments rather than governmental calculation.

However, these liberal measures proved to be half-hearted. First, the pricing for a monthly advance payment for a patent is unbalanced: in some regions of Russia it is inadequate to their migration attractiveness (Maleva et al., 2016) [17]. Second, there are many requirements for obtaining a patent. One of them is a compulsory test in the Russian language, Russian history, and the basics of law (this also applies to seasonal workers who do not plan to stay in Russia).

Furthermore, many Russian regions require immigrants to indicate their profession while obtaining a patent, and in case of a mismatch between the actual work and 
the indicated profession the "offenders" are to be punished. Thus, each step towards liberalization is accompanied by a subsequent reversion to restrictive measures. The tactic of the Russian authorities is to combine permissive and restrictive techniques, while maintaining tight control in the hands of police structures.

\subsection{Producing Illegality}

Shortly after his election for a third term (2012), Vladimir Putin took an important symbolic step in migration policy. He approved the document called "The Concept of the State Migration Policy through to 2025," which for the first time outlined the contours of a long-term strategy for attracting migratory resources. ${ }^{11}$ It is noteworthy that the Concept emphasized not temporary foreign labor, but rather the need to involve immigrants on a long term basis to address demographic challenges. In addition, the Concept stated that migration is helpful for the sustainable development of Russia. One of the document's explicit objectives was attracting talented foreign workers who will contribute to the country's modernization.

However, the goals set in the Concept are unlikely to be achieved due to the institutional environment of migratory regulation. Because of the illiberal nature of the current political regime in Russia the set of players who may influence the decision-making process in the field of migration policy is very limited; the decisions are taken in a non-transparent way. At the same time, those in power are able to impose unpopular solutions in practice. The latter include all attempts to liberalize the legislation on foreign workers.

Despite the fluctuations between restrictive and permissive logic, the key players in migration policy are not interested in a significant reshaping of the relations between the state and migrants. The peculiarity of these relations is that (a) the overall direction of the legislative process acquires a restrictive character and (b) there is an essential corruption component in law enforcement practice, which is largely due to the design of the laws themselves.

Even when the legislation on migrants has been liberalized, subsequent interventions are usually directed toward the tightening of the rules of entry and residence. Because of multiple legislative initiatives (in the form of bylaws) the rules of foreign labor legalization become confusing and chaotic - most migrants do not have an opportunity to adapt to them. ${ }^{12}$ Frequent legislative innovations are not accompanied by information campaigns for migrants. As a result, foreign workers use their own social networks as their source of information, which leads to false knowledge about the procedures for legalizing labor activity. Many migrants are not aware they are violating the law.

The very design of certain legislative acts concerning migration causes corruption. Thus, in 2013 the so-called "law on rubber flats" was adopted. The law was aimed at creating obstacles to the registration of tens and even hundreds of foreign nationals at the same address. In fact, instead of contributing to the achievement of this goal, the law prevented it. The only thing this law 
accomplished was the worsening of the lives of those Russian citizens who register foreign nationals in their apartments, because they were required to reside at the place of registration. "Rubber flats" exist because of the connivance of the relevant regulatory authorities. The spread of such registration practices is not the result of migrants' malice, but of their inability to obtain registration otherwise. The prohibitions contained in this law stimulated not the obedience of the citizens, but, on the contrary, their attempts to bypass the law.

Corruption manifests itself in the contradiction between the legislation norms of law enforcement practice and the highly bureaucratized non-transparent procedures for obtaining work and residence permits. Instances that are responsible for the issuance of such documents often hamper the process for their production, and thereby force migrants to pay bribes. ${ }^{13}$

In recent years, Russian authorities have adopted more stringent rules of stay for migrants, portraying this as a means of restoring order. In January 2014 the socalled "90/180/90" rule came into effect. Its essence lies in the fact that migrants from states that have a visa-free regime with Russia can legally stay in the country only for 90 days during a 180-day period; then they must leave the territory of Russia and can return only after 90 days have elapsed since their departure. Instead of reducing the number of undocumented migrants, this rule has increased the size of bribes that offenders provide to inspection bodies. This measure, in particular, has led to a decrease in the number of legally employed workers, despite the availability of a patent. As of March 2016 their number was 1.7 million, even though at least three times more migrants are present in the Russian labor market (Florinskaya and Mkrtchyan, 2016) [18].

Thus, a considerable number of Russian officials perceive migration control and migrants themselves as a source of income. The low level of Russia's immigration attractiveness is not seen as a problem, as long as the material interests of those responsible for the regulation of migration are satisfied.

\subsection{The Primacy of Politics over the Economy}

On April 5, 2016, Russian President Vladimir Putin signed a decree on the elimination of the Federal Migration Service as a separate agency. Since then, migration management functions have been transferred to the Ministry of the Interior. The staff of FMS (reduced by 30 percent) joined the General Directorate on Migration Issues established within the ministry. From the perspective of the external observer, the institutional framework of Russian migration policy has now reverted to that of 2002 in a sense. However, we should not forget that being a separate agency during those 12 years the FMS kept seeing itself as a police structure par excellence. This became evident in the spring of 2014, when the agency proposed a draft law "On Immigration Control", which aimed at a significant expansion of its power functions. If this law had been approved by the State Duma, the FMS would have acquired the right to inspect enterprises, cancel their licenses, and withdraw authorization for employers. In addition, FMS demanded for its staff the right to initiate and investigate criminal cases concerning 
illegal migration, check the migrants' IDs, and use weapons (Mihaylova, 2016) [3]. But Vladimir Putin decided that the state does not need two security agencies with overlapping functions and the FMS was abolished. It is assumed that labor migration issues (including the issuing of work permits - "patents"'), as well as civic integration programs (training courses and exams on knowledge of Russian language and legislation) will be handed over to the Ministry of Labor and the Ministry of Education, respectively, as well as to local authorities. However, despite the fact that this transfer is noted in official statements (Vashchenko, 2016) [22], it is not yet established at the institutional level. The concentration of migration management tools in the hands of security agencies indicates that priority is given to the police approach, rather than the economic one. At the same time the Russian government is clearly interested in strengthening economic integration in the framework of the EAEU. Citizens of EAEU member states have a privileged mode of employment in Russia. They are freed from the necessity to obtain a patent and, therefore, the obligation to take exams on the Russian language and the basics of legislation. The question of the expansion of the EAEU creates a contradiction between foreign and domestic political priorities among conservative-minded elements of the Russian elite. On one side of the scale are Russia's ambitions as a regional superpower and the engine of the "reintegration process", on the other - the administrative control of migration inflow.

Whatever they may be, the EAEU member states are not the main suppliers of labor, while Tajikistan, a traditional migration donor for Russia, seeks to join the EAEU largely because of the preferential mode of employment for its citizens. In 2014 an agreement was signed between the governments of Russia and Tajikistan, according to which Tajik migrants were granted the right to obtain work permits for up to three years instead of one year. New legislation revoked these preferences. Moreover, since 2015, citizens of Tajikistan may enter Russia only with biometric passports, while the citizens of the EAEU member states can do so with an internal ID.

The primacy of foreign policy rationales prevented Russia from taking the opportunity provided by an unprecedented influx of immigration from Ukraine. As mentioned above, in 2015, Ukrainian citizens (predominantly from the south-east part of Ukraine) constituted 64 percent of the entire migration increase in Russia). In the initial phase of the Ukrainian crisis, the Russian government took steps to establish most-favored-nation treatment of Ukrainian migrants. In addition to the temporary accommodation centers for refugees from south-east Ukraine there was a whole range of possibilities - from temporary asylum and refugee status to participation in the state program for the resettlement of compatriots. The most important measure was a government decree according to which Ukrainian citizens could find work in Russia without obtaining permits (or purchasing a patent). There was a great opportunity to gain much-needed long-term growth of the population through people whose integration into the Russian socio-cultural environment does not require much effort. Instead, the Russian government decided to use tightening of the immigration rules as a way to pressure the Ukrainian authorities in conditions of a sharp deterioration in relations between the 
two countries. After one and a half years, Russia changed its policies toward Ukrainian citizens: from 1 November 2015 the citizens of Ukraine were equated with other foreigners from visa-free countries. The " $90 / 180 / 90$ " rule was applied to them.

Subordination to foreign policy concerns is not just a recent phenomenon in Russian migration policy. Thus, in the fall of 2006, after Georgian authorities arrested five Russian servicemen, a campaign was launched in major Russian cities against Georgian immigrants. The enterprises owned by Georgians were subjected to inspections, the public schools were asked to provide lists of children with Georgian names in order to identify "illegal migrants", and thousands of Georgian citizens were expelled from Russia due to alleged "violations of immigration rules". These actions outraged human rights organizations and were met with resistance on the part of teachers and civil society activists. Similarly, in 2011 in response to the arrest of two pilots of a Russian airline (Rolkan Investments Ltd.) in Tajikistan (they were accused of smuggling) the FMS launched a mass deportation of Tajik undocumented migrants. Finally, citizens of Turkey living and working in Russia faced negative treatment by the Russian authorities after a Russian military bomber was shot down by Turkish troops on the border with Syria in November 2015.

In the absence of domestic political irritants, migration policy is affected mainly by external political stimuli. An exception was a mayoral election in Moscow in 2013, when opposition leader Alexei Navalny was a major competitor against Sergei Sobyanin (a representative of the ruling party). Navalny is known for his anti-immigration rhetoric (in particular, during the pre-election debate, he proposed introducing a visa regime with the Central Asian republics), and his agenda was in some sense appropriated by the Moscow authorities. Thus, in August 2013 in the Moscow area Golyanovo, a camp for "illegal immigrants", was established. It contained violators of the residence regime caught by police during their raids on Moscow markets. The formal reason for creating the camp was the attack on a police officer at one of the Moscow small wholesale markets, which had occurred shortly before. Despite the fact that the attacker was a Russian citizen (a native of Dagestan), the main victims of the campaign were Vietnamese workers. In addition, the camp contained the citizens of Azerbaijan, Uzbekistan, and Tajikistan.

The Russian ruling elite seems not to be fully aware of the increasing competition for workers from the NIS, both with external players (that is, those outside the post-Soviet space, such as China, Turkey, and the EU), as well as with internal players, primarily Kazakhstan. Their belief that Russia will remain the main migration magnet for former Soviet citizens does not look sustainable if one takes a look at demographic forecasts. Liberal economists insist that the positive economic effects of immigration should not suffer from political conjunctures. At the same time there are many experts close to the government who rely on the fostering of internal migration (as opposed to immigration) in order to overcome the shortage of labor. However, this scenario assumes a huge depopulation of the "give up" territories. From that, the future of Russian migration policy will largely 
depend on which of these two expert camps will be privileged by the Russian president. At the moment, two alternative strategies of socio-economic development for Russia through to 2030 are being developed on behalf of Vladimir Putin. One (liberal) is prepared by the Center for Strategic Research, headed by Alexei Kudrin, the other (more conservative) - by the experts of the "Stolypin Club".

\section{Conclusion}

With regard to the regulation of migration, the Russian case is quite specific when compared with that of liberal democracies of the West. This specificity is generated by an extreme level of "securitization" of migration and by the corrupt practices that pervade the whole of migration regulation.

The government considers the immigration issue primarily through a policing lens. One cannot claim that the Russian state does not take any steps to liberalize "migratory regulation". However, the effect of these measures is being "extinguished" almost immediately by new restrictions. This is due to the prevalence of security logic over a logic of development as well as to the merely material motives of interest groups in bureaucracy and big business. The liberally designed laws do not bring the expected result (i.e., reduction of undocumented employment and an increase in tax revenue). These laws soon after being passed become cluttered with amendments and bylaws which prevent them from being implemented. In addition, the collision between foreign policy and domestic policy rationales contributes considerably to the inconsistency of Russian migratory regulation. While "geopolitical" ambitions imply measures to expand Russia's influence in the post-Soviet space, domestic policy is directed by imperatives such as strengthening national sovereignty. It goes without saying that this imperative is hardly compatible with large-scale immigration for settlement.

\section{Acknowledgments}

The authors would like to thank Tatyana Maleva, Julia Florinskaya, Nikita Mkrtchyan, Irina Ivakhnyuk, Sergey Ryazantsev and Vladimir Mukomel whose instructive studies on various aspects of the Russian immigration provided us with the necessary information. Special thanks to Jan M. Surer for editing our imperfect English.

\section{Author Contributions}

Both authors contributed equally to this work.

\section{Conflicts of Interest}

The authors declare no conflicts of interest. 


\section{References}

1. Freeman, G.P. Modes of Immigration Politics in Liberal Democratic States. The International Migration Review 1995, 29, 881-902.

2. Shleifer, A.; Treisman, D. A Normal Country: Russia After Communism. J. Econ. Perspect. 2005, 19, 151-174.

3. Mihaylova, I. Russia's New Concept of the State Migration Policy: Recommendations for Effectiveness of International Economic Migration; University of St. Gallen Law \& Economics Working Paper No. 2016-03; University of St. Gallen Law School, Law and Economics Research Paper Series, 2016.

4. Demografiia (Demography); Russian Federal Statistics Service. Available online: http://www.gks.ru/wps/wcm/connect/rosstat_main/rosstat/ru/statistics/population/demograp hy/\# (accessed on 31 August 2016).

5. Trud i zaniatost'v Rossii (Labor and employment in Russia); Collection of statistics; Russian Federal Statistics Service, 2015. Available online: http://www.gks.ru/free_doc/doc_2015/trud15.pdf (accessed on 15 August 2016).

6. Florinskaya, Y.; Mkrtchyan, N.; Maleva, T.; Kirillova, M. Migratsiia i rinok truda (Migration and the labor market); Series "Scientific reports: Social policy", Institute of Social Analysis and Forecasting of the Russian Academy of National Economy and Public Administration; Delo: Moscow, Russia, 2015.

7. Malakhov, V.; Mkrtchyan, N.; Vendina, O.; Florinskaya, Y.; Varshaver, E.; Rocheva, A; Postavnin, V.; Vlasova, N.; Simon, M.; Samson, I. Mezhdunarodnaia migratsiia $i$ ustoichivoe razvitie Rossii (International migration and the sustainable development of Russia); Series "Scientific reports: Social policy", Russian Academy of National Economy and Public Administration; Delo: Moscow, Russia, 2015.

8. Romodanovsky, K.; Mukomel, V. Regulirovanie migratsionnykh protsessov: problemy perekhoda ot reaktivnoi k sistemnoi politike (The regulation of migration processes: The transition from a reactive to a system policy). Obshchestvennye nauki i sovremennost' (Social sciences and modernity) 2015, No. 5, 5-18.

9. Chudinovskikh, O.; Denisenko, M.; Mkrtchyan, N. Vremennye trudovye migranty v Rossii (Temporary labor migrants in Russia). Demoscope-Weekly 2013, No. 579-580. Available online: http://demoscope.ru/weekly/2013/0579/tema01.php (accessed on 1 September 2015).

10. Lunkin, A.; Denisenko, M.; Zayonchkovskaya, Z.; Karachurina, L.; Mkrtchyan, N.; Semikin, D.; Turukanova, E.; Florinskaya, Y.; Yakubovskiy, E. Migratsiia kak faktor razvitiia malogo i srednego biznesa i ekonomiki Rossii (Migration as a factor of development of small and medium enterprises and the economy of Russia); Opora Rossii: Moscow, Russia, 2010.

11. Varshavskaya, E.; Denisenko, M. Inostrannye rabotniki na rossiiskom rinke truda: kharakteristiki, mobil'nost, zarplata (po rezultatam issledovaniia) (Foreign workers in the Russian labor market: Characteristics, mobility, salaries [based on research results]). In Regulirovanie ekonomicheskoi migratsii: deistvuiushchie mekhanizmy i praktiki 
privlecheniia, otbora i dopuska rabochei sily $i$ vozmozhnosti koordinirovannogo upravleniia trudovoi migratsiei v Vostochnoi Evrope i Tsentralnoi Azii (The regulation of economic migration: Existing mechanisms and practices of attraction, selection and admission of foreign labor and the possibility of labor migration coordinated governance in Eastern Europe and Central Asia), Materials of regional practical seminar, Bureau of International Organization for Migration in Moscow, Moscow, Russia, 2014; 91-110.

12. Ryazantsev, S.V. Vliianie trudovoi migratsii na ekonomiku Rossii: metody i rezultaty (The impact of migration on the Russian economy: Methods and results). In Transnatsional'nye migratsii i sovremennye gosudarstva $v$ usloviiakh ekonomicheskoi turbulentnosti (Transnational migrations and modern states in conditions of economic turbulence); Malakhov, V., Simon, M., Eds.; Delo: Moscow, Russia, 2016; pp. 188-214.

13. Obsledovaniia naseleniia po problemam zaniatosti - $2015 \operatorname{god}$ (Investigation of the population concerning employment problems - 2015); Russian Federal Statistics Service. Available online: http://www.gks.ru/bgd/regl/b15_30/Main.htm (accessed on 1 September 2016).

\section{Analiz praktik trudovykh otnoshenii inostrannykh grazhdan (trudovykh migrantov) $i$ ikh} vliianiia na transformatsiiu trudovykh otnoshenii rossiiskikh grazhdan (Analysis of foreign nationals' [labor migrants'] labor relations practices and their impact on the transformation of Russian citizens' labor relations); Center for Social and Labor Rights: Moscow, Russia, 2013. Available online: http://trudprava.ru/expert/research/migrationsurv/771 (accessed on 1 September 2016).

15. Turukanova, E.; Florinskaya, Y. Inostrannaia rabochaia sila na rinke truda Rossii (The foreign labor force in the Russian labor market). Demoscope-Weekly, 2012, No. 535-536. Available online: http://demoscope.ru/weekly/2012/0535/analit06.php\#_FN_1 (accessed on 2 September 2016).

16. Svedeniia o dostizhenii znachenii pokazatelei (indikatorov) podprogrammy 2 "Vneshniaia trudovaia migratsiia"Gosudarstvennoi programmy Rossiiskoi Federatsii 7 "Sodeistvie zaniatosti naseleniia" po itogam 2015 goda (Information on attaining the significance of measures [indicators] of the sub-program 2 "External labor migration" of the state program of the Russian Federation 7 "Facilitation of the employment of the population" based on the results of 2015); General Directorate on Migration Issues of the Interior Ministry of Russia. Available online: https://xn--b1ab2a0a.xn--b1aew.xn-plai/about/activity/stats/Ezhegodnie_dokladi_2/item/60289 (accessed on 31 August 2016).

17. Maleva, T.; Avraamova, E.; Burdiak, A.; Grishina, E.; Zubarvich, N.; Kirillova, M.; Loginov, D.; Lyashok, V.; Mkrtchyan, N.; Poliakova, A.; Tindik, A.; Florinskaya, Y.; Hasanova, R.; Tzatsura, E. 2014-2015 gody: ekonomicheskii krizis - sotsial'noe izmerenie (2014-2015: Economic crisis - the social dimension); Series "Scientific reports: Social policy", Russian Academy of National Economy and Public Administration; Delo: Moscow, Russia, 2016.

18. Florinskaya, Y.; Mkrtchyan, N. Resursy migratsionnogo prirosta istochilis' (Migration population increase resources are exhausted). In Operativnyi monitoring situatsii v Rossii: tendentsii $i$ vyzovy sotsial'no-ekonomicheskogo razvitiia. (Real-time monitoring of the economic situation in Russia: Trends and challenges of socio-economic development), No.6 (24) April 2016; Gaidar Institute of Economic Policy, Russian Academy of National Economy and Public Administration, Russian Foreign Trade Academy. Available online: 
http://www.iep.ru/files/text/crisis_monitoring/2016_6-24_april.pdf (accessed on 15 August 2016).

19. Mukomel, V. Migratsionnaia politika Rossii. Postsovetskie konteksty (Russian migration policy: Post-Soviet contexts); Institute of Sociology of the Russian Academy of Sciences; Dipol \& T.: Moscow, Russia, 2005.

20. Ivakhnyuk, I. Rossiiskaia migratsionnaia politika i ee vozdeistvie na chelovecheskoe razvitie: istoriia i sovremennost' (Russian migration policy and its impact on human development: History and modernity). In Mezhdunarodnaia migratsiia naseleniia: Rossia $i$ sovremennyi mir (International migration of population: Russia and the Modern World), Issue No.22; Faculty of Economics of the Lomonosov Moscow State University; Moscow, Russia, 2009.

21. Concept of the State Migration Policy of the Russian Federation through to 2025; President of Russia Web site. Available online: http://en.kremlin.ru/events/president/news/15635 (accessed 2 September 2016).

22. Vashchenko, V. K uchastkovomu za pasportom idti ne pridetsia: Glava upravleniia po voprosam migratsii MVD Ol'ga Kirillova dala interv'iu "Gazete.Ru" (You won't have to go to the local police for a passport: The head of the Administration for Migration Issues of the Interior Ministry Ol'ga Kirillova gave an interview to Gazeta.Ru). Gazeta.ru, June 30, 2016. Available online: https://www.gazeta.ru/social/2016/06/30/8348279.shtml (accessed 2 September 2016).

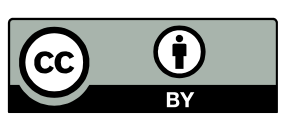

(C) 2016 by the authors; licensee Preprints, Basel, Switzerland. This article is an open access article distributed under the terms and conditions of the Creative Commons by Attribution (CC-BY) license (http://creativecommons.org/licenses/by/4.0/).

\footnotetext{
${ }^{1}$ According to official data migrants account for 5 percent of the labor force in construction, but experts estimate their share in this branch at 20 percent. The share of foreign workers in housing maintenance and in transport in large cities such as Moscow and St.Petersburg might be even higher. For example, it would be hard to find a Russian citizen among cleaners in Moscow.

${ }^{2}$ Whereas the shadow economy includes all kinds of unregistered (and thus non-taxable) economic activity (including criminal activity), the informal economy is characterized by the fact that it is unobservable by the state. For example, there is no official data on the employment of foreign workers on farms.

${ }^{3}$ See Obsledovaniia naseleniia po problemam zaniatosti - 2015 god (Investigation of the population concerning employment problems) [13].

${ }^{4}$ See Svedeniia o dostizhenii znachenii pokazatelei (Information on attaining the significance of measures) [16].

${ }^{5}$ For comparison, in 2014 the population increase due to immigration amounted to 270 thousand people and in 2013 — 296 thousand (Maleva et al., 2016) [17].

${ }^{6}$ The author refers to the data provided by the Federal Migration Service. The data track formal employment: professions specified in work permits and patents for labor activity for individuals (i.e., in households). It can be assumed that the data have been collected on the basis of this information. However, many people do not actually work in the profession they indicate, not to mention undocumented migration. Therefore it is necessary to note that employment of immigrants in households in fact is not as high as stated.
} 
${ }^{7}$ According to the Federal Law "On the Legal Status of Foreign Citizens in the Russian Federation" (July 25, 2002), foreign nationals had to register no later than three days after entry; the term of temporary stay for citizens of states with a visa-free regime with Russia could not exceed 90 days; and foreign citizens did not have the right to change their place of residence within the region. In addition, the government set quotas for the issuance of temporary residence permits. The law did not provide privileges in employment for citizens of the former USSR. This aroused the indignation of public organizations, and a year later (in 2003) amendments facilitating temporary and long-term stays for immigrants from the CIS countries were adopted.

${ }^{8}$ The laws were developed and adopted in 2006.

${ }^{9}$ In addition, foreign nationals were forbidden to trade in the markets, as well as to seek employment in a number of retail areas (such as alcohol and medical products).

${ }^{10}$ Many immigrants in the period from 2011 to 2014 preferred to obtain a patent, which allowed them to work for individuals, but they were actually employed in firms, companies and organizations.

${ }^{11}$ The Concept outlined three main stages. At the first stage (2012-2015) it was supposed to set the design of the main state programs in the corresponding fields and to create an infrastructure for the integration of migrant workers. The second stage (2016-2020) involved implementing and monitoring these programs and the third one (2021-2025) was to include assessing the policy's implementation. See "Concept of the State Migration Policy of the Russian Federation through to 2025" [21].

${ }^{12}$ Thus, 54 amendments were made to the Federal Law "On the Legal Status of Foreign Citizens" (adopted in 2002) and 16 amendments to the Federal Law "On Migration Registration of Foreign Citizens and Stateless Persons" (adopted in 2006). Most of them were restrictive.

${ }^{13}$ Replacing the quota system with patents for carrying out work for legal entities should have led to an increase in the number of legal workers, but the result was far from perfect. The package of documents required from the foreign worker is so great that a lot of effort is required to buy it. That is why many migrants make a decision not to go through the process of legalizing their work. 